\title{
Pemberian Makanan Tambahan dan Susu Terhadap Penambahan Berat Badan Pada Ibu Hamil KE (Kekurangan Energi Kronis) di Tangerang Tahun 2018
}

\author{
Vivi Silawati ${ }^{1}$, Nurpadilah ${ }^{1}$ \\ ${ }^{1}$ Fakultas Ilmu Kesehatan Universitas Nasional \\ Jl. RM Harsono No. 1 Ragunan, Pasar Minggu Jakarta Selatan, 12550 \\ Email: v.silawati@gmail.com
}

\begin{abstract}
ABSTRAK
Pendahuluan Ibu hamil yang menderita gizi kurang seperti kurang energi kronik mempunyai resiko kesakitan yang lebih besar oleh karena itu kurang gizi pada ibu hamil harus dihindari sehingga ibu hamil merupakan kelompok sasaran yang perlu mendapat perhatian khusus. Penelitian ini bertujuan untuk mengetahui pengaruh pemberian makanan tambahan dan susu ibu hamil terhadap kenaikan berat badan pada ibu hamil KEK. Metodologi: Penelitian quasi-experiment ini menggunakan rancangan One Group Pretest-Postest Design tanpa adanya kelompok kontrol. Sampel dalam penelitian ini berjumlah 16 ibu hamil trimester I yang menderita KEK. Hasil penelitian menunjukkan bahwa ada perbedaan yang signifikan pada berat badan ibu hamil sebelum dan sesudah diberikan makanan tambahan dan susu ibu hamil pada kelompok eksperimen $(\mathrm{p}<0,05)$. Kesimpulan: Pemberian makanan tambahan dan susu ibu hamil berpengaruh terhadap kenaikan berat badan pada ibu hamil KEK. Program ini dapat diaplikasikan di praktik kebidanan khususnya pasien hamil trimester I dengan KEK dan sebagai bahasan rujukan untuk penelitian selanjutnya.
\end{abstract}

Kata Kunci: Ibu Hamil, KEK, Pemberian Makanan Tambahan, Susu Hamil

\section{Supplementary Food and Milk On Body Weight Gain Among Chronic Energy Deficiency Pregnant Women in The Work Area of Tangerang Regency in 2018}

\begin{abstract}
Background: Pregnant women who suffer from malnutrition such as lack of chronic energy have a greater risk of illness, therefore malnutrition in pregnant women should be avoided so that pregnant women are the target group that needs special attention. Objective: This study aims to determine the effect of supplementary feeding and milk on pregnant women on weight gain amongchronic energy deficiency pregnant women in the Curug District Health Center in Tangerang in 2018. Methodology: This quasi-experimental study uses the design of One Group Pretest-Postest Design without a control group. The sample in this study amounted to 16 first trimester pregnant women who suffered chronic energy deficiency, the sampling technique used was total sampling. The research instrument to measure upper arm and scales to measure the weight of pregnant women, as well as a checklist sheet used to record upper arms size and weight before and after intervention. Data were analyzed using paired $t$ test. Results: The results showed that there was a significant difference in the weight of pregnant women before and after intervention in the experimental group ( $p<0.05)$. Conclusions Giving supplementary food and milk to pregnant women influences weight gain among chronic energy deficiency pregnant women. This program can be applied in midwifery practice especially for first trimester pregnant patients with chronic energy deficiency and as a reference for future research.
\end{abstract}

Keywords: pregnant women, chronic energy deficiency, supplementary food, milk 


\section{Pendahuluan}

Tercapainya kualitas hidup yang baik bagi keluarga dan masayarakat sangat ditentukan oleh kesehatan ibu dan anak. Ibu hamil adalah salah satu kelompok yang rawan akan masalah gizi. Organisasi Kesehatan Dunia (WHO) melaporkan bahwa prevalensi KEK (Kekurangan Energi Kronik ) pada kehamilan secara global $35-75 \%$ dimana secara bermakna tinggi pada trimester ketiga dibandingkan dengan trimester pratama dan kedua kehamilan. WHO juga mencatat $40 \%$ kematian ibu di negara berkembang berkaitan dengan kekurangan energi kronis. Ibu hamil yang menderita gizi kurang seperti kurang energi kronik mempunyai resiko kesakitan yang lebih besar oleh karena itu kurang gizi pada ibu hamil harus dihindari sehingga ibu hamil merupakan kelompok sasaran yang perlu mendapat perhatian khusus. Kejadian kekurangan energi kronis di negara- negara berkembang seperti Bangladesh, India, Indonesia, Myanmar, Nepal, Srilangka dan Thailand adalah 15-47\% yaitu dengan BMI <18,5. Adapun negara yang mengalami kejadian KEK pada ibu hamil tertinggi adalah Bangladesh yaitu 47\%, sedangkan Indonesia merupakan urutan ke empat terbesar setelah India dengan prevalensi $35,5 \%$ dan yang paling rendah adalah Thailand dengan prevalensi $15-25 \%$ ( WHO, 2015 ).

Hasil laporan kinerja Ditjen Kesehatan masyarakat tahun 2016 melaporkan bahwa persentase ibu hamil KEK di Indonesia sebesar 16,2\% (Kemenkes, 2017). Hasil pemantaun gizi (PSG) tahun 2016 melaporkan bahwa Provinsi Banten adalah salah satu provinsi dengan angka resiko ibu hamil KEK (jumlah ibu hamil dengan lingkar lengan atas $<23,5 \mathrm{~cm}$ ) sebesar $18 \%$, angka tersebut diatas rata-rata persentasi nasional yaitu sebesar $16,2 \%$. Persentasi tertinggi adalah Provinsi Papua sebesar 23,8\% dan terendah Provinsi Sumatera Utara sebesar 7,6\% (Kemenkes, 2017).
Berdasarkan data jumlah ibu hamil yang mendapatkan PMT tahun 2018 yaitu $25,2 \%$ dari jumlah ibu hamil dan bias disimpulakan terdapat $25,2 \%$ ibu hamil memiliki LILA kurang dari $23,5 \mathrm{~cm}$ atau di sebut dengan ibu hamil KEK, dan dari 25,2\% ibu hamil yang KEK dan harus mendapatkan PMT ( Pemberian Makanan Tambahan ) baru $89,7 \%$ yang mendapat program PMT dari 25,2\% jumlah ibu hamil KEK dan 10,3\% ibu hamil KEK yang belum mendapatkan PMT ( Profil Kesehatan Kementrian Republik Indonesia 2018). Berdasarkan data yang diperoleh dari tempat penelitian yaitu Puskesmas Curug Kabupaten Tangerang Jumlah ibu hamil KEK tahun 2017 yaitu 67 ibu hamil dan terdaftar mendapatkan PMT (Pemberian Makanan Tambahan). Dan pada tahun 2018 jumalah ibu hamil KEK mengalami kenaikan yaitu jumlah kumulatif bulan November 2018 yaitu 78 ibu hamil dengan LILA kurang dari $23,5 \mathrm{~cm}$ atau disebut ibu hamil KEK.

Permasalahan diatas semakin meningkatnya data ibu hamil yang KEK setiap tahun, dimana kita ketahui KEK dapat menyebabkan perdarahan pada ibu hamil pada saat hamil dan bersalin, sedangkan penyebab kematian ibu tertinggi masih disebabkan oleh perdarahan yaitu $30 \%$ dari jumlah kematian ibu setiap tahunnya, maka peneliti melakukan penelitian dengan judul "Pemberian Makanan Tambahan dan Susu Terhadap Penmabahan Berat Badan pada Ibu Hamil KEK (Kekurangan Energi Kronik) di Wilayah Kerja Puskesmas Curug Kabupaten Tangerang Tahun 2018"

\section{Metode Penelitian}

Metode yang digunakan dalam penelitian ini adalah desain penelitian Quasi Experimen (eksperimen semu) dengan rancangan yang digunakan adalah One Group Pretest- Postest Design tanpa adanya kelompok kontrol tetapi sudah dilakukan observasi pertama (pretest) yang mungkin peneliti dapat menguji perubahan - perubahan yang terjadi setelah adanya ekspermen (postest), (Notoatmodjo, 2010). 
Desain Quasi Experimen merupakan penelitian yang digunakan untuk mengetahui ada tidaknya akibat dari "sesuatu" yang akan dikenakan pada subjek yang akan diteliti dengan mencari pengaruh perlakuan tertentu terhadap yang lain dalam kondisi yang terkendali, (Sugiyono,2012). Hal ini berarti eksperimen merupakan kegiatan percobaan untuk meneliti suatu peristiwa atau gejala yang muncul pada kondisi teretntu. One Group Pretest Postestadalah suatu teknik untuk mengetahui efek sebelum dan sesudah diberikan perlakuan, (Sugiyoni, 2012). Penelitian ini dilakukan bulan desmeber
2018 sampai dengan januari 2019 di Wilayah Kerja Puskesmas Curug Kabupaten Tangerang.

Instrument yang di gunakan lembar obsevasi dan lembar kontrol, dilakukan uji normalitas dengan menggunakan Shapiro - Wilk, dan dilakukan uji bivariat untuk mengetahui apakah ada pengaruh pemberian makanan tambahan dan susu terhadap penambahan berat badan pada ibu hamil kek di wilaya kerja Puskesmas Curug Kabupaten Tangerang Banten Tahun 2018 dengan menggunakan uji statistik Paired T test.

\section{Hasil Penelitian}

Table 1 Distribusi Frekuensi Berdasarkan Lingkar Lengan Atas (LILA) Di Wilayah Kerja Puskesmas Curug Kabupaten Tangerang Tahun 2018

\begin{tabular}{ccccccc}
\hline \multicolumn{2}{l}{ Lingkar lengan atas } & & & & & \\
\hline $\mathrm{N}$ & $\%$ & Mean & SD & Median & Min & Max \\
\hline 16 & 100 & 21,91 & 1.052 & 22.00 & 21 & 23 \\
\hline
\end{tabular}

Tabel 2 Distribusi Frekuensi Rata - rata Berat Badan Sebelum Perlakuan Dan Sesudah Diberikan Makanan Tambahan dan Susu Ibu Hamil Pada Ibu Hamil

\begin{tabular}{lllccccc}
\hline $\begin{array}{l}\text { Kelompok } \\
(\mathrm{n}=16)\end{array}$ & Perlakuan & & & & & & \multicolumn{2}{c}{ Nilai berat badan } \\
\cline { 6 - 8 } & $\mathrm{N}$ & $\%$ & Mean & SD & Median & Min & Max \\
Sesum & 16 & 100 & 44 & 3.198 & 44 & 39 & 58 \\
\hline
\end{tabular}

Dari Tabel 2 karakteristik responden berdasarkan berat badan sebelum di berikan perlakuan di dapatkan hasil rata rata berat badan ibu $44 \mathrm{~kg}$. dengan standart deviasi 3,198 sedangkan untuk berat badan minimum $39 \mathrm{~kg}$, dan berat badan maximum $41 \mathrm{~kg}$. dari table di atas, didapatkan hasil lainnya yaitu berat badan ibu setelah di beri perlakuan, dengan berat rata rata $46 \mathrm{~kg}$, dengan nilai minimum 41 $\mathrm{kg}$. dan nilai maximum $60 \mathrm{~kg}$.

Data uji normalitas diperoleh dari hasil sebelum dan sesuadah diberikan makanan tambahan dan susu ibu hamil dengan menggunakan metode Shapiro -
Wilk yaitu uji nonparametris untuk mengukur signifikan perbedaan antara 2 kelompok data berpasangan bersekala rasio dan interval tetapi berdistribusi normal. Taraf signifikan $95 \%(\alpha=0,05)$. Pedoman dalam menerima hipotesis, apabila $\mathrm{p}$ value $<0,05$ maka Ho gagal ditolak yaitu tidak ada pengaruh, dan bila $\mathrm{p}$ value > maka Ho ditolak yaitu ada pengaruh (Sutanto, 2006 ). Pada penelitan diperoleh hasil nilai Pvalue adalah lebih dari 0,005 . Dengan demikian, dapat disimpulkan bahwa distribusi data adalah normal sehingga bisa dilakukan analisis bivariate. 
Table 3 Pengaruh Pemberian Makanan Tambahan dan Susu Ibu Hamil Terhadap Penambahan BB pada Ibu Hamil KEK

\begin{tabular}{lllll}
\hline Kelompok Perlakuan $(\mathrm{n}=16)$ & Mean & SD & T & P \\
\hline Sebelum Perlakuan & -1.813 & 750 & $-9,667$ & 0,000
\end{tabular}

Berdasarkan table 3 maka didapatkan hasil dengan mean sebelum diberikan perlakuan 44 dan sesudah diberikaan perlakuan didapatkan hasil rata - rata $46 \mathrm{~kg}$ mean dari keduanya yaitu 1,813dengan standar devisiasi 750 selain itu didapatkan juga nilai $\mathrm{P}=0,00<0,05$ maka didapatkan adanya pengaruh antara sebelum perlakuan dan setelah perlakuan.

\section{Pembahasan \\ Lingkar Lengan Atas pada Ibu Hamil KEK}

Hasil penelitian yang dilakukan di Wilayah Kerja Puskesmas Curug didapatkan rata rata nilai Lila $21,91 \mathrm{~cm}$. dengan standart deviasi 1.052 sedangkan untuk lingkar lengan minimum $21 \mathrm{~cm}$ dan maximum $23 \mathrm{~cm}$. Lingkar lengan atas (LILA) adalah jenis pemeriksaan antropometri yang digunakan untuk mengukur risiko KEK pada wanita usia subur yang meliputi remaja, ibu hamil, ibu menyusui dan Pasangan Usia Subur (PUS). Sedangkan ambang batas LILA pada WUS dengan resiko KEK adalah $23,5 \mathrm{~cm}$ dan apabila kurang dari $23,5 \mathrm{~cm}$ wanita tersebut mengalami KEK (Supriasa, 2012).

Hasil penelitian sesuai dengan penelitian Laila Siti Azzahra 2016 dimana dari 42 responden, terdapat 25 responden $(59,4 \%)$ mengalami KEK di Puskesmas Belimbing Padang tahun 2016. Menurut asumsi peneliti sesuai data yang didapat pada saat penelitian ibu hamil KEK yaitu ibu hamil yang mempunyai LILA $<23,5 \mathrm{~cm}$ dimana disebabkan karena nutrisi ibu belum terpenuhi, dari sebab itu kebutuhan nutrisi ibu hamil KEK harus diberikan makanan tambahan dan setelah diberimakan makanan diliahat apakah ada perubahan status gizi yaitu dengan melakukan pengukuran LILA berikutnya, status gizi yang kurang juga bias dicegah pada saat masa remaja sehingga persiapan untuk hamil status gizi sudah baik.

\section{Rata - Rata Berat Badan pada Ibu Hamil KEK Sebelum dan Sesudah Diberikan Makanan Tambahan dan Susu}

Hasil Penelitian yang dilakukan di Wilayah Kerja Puskesmas Curug Kabupaten Tangerang Tahun 2018 didapatkan hasil berdasarkan berat badan sebelum di berikan perlakuan di dapatkan hasil rata rata berat badan ibu $44 \mathrm{~kg}$. dengan standart deviasi 3,198 sedangkan untuk berat badan minimum $39 \mathrm{~kg}$. dan berat badan maximum $41 \mathrm{~kg}$. dari table di atas, didapatkan hasil lainnya yaitu berat badan ibu setelah di beri perlakuan, dengan berat rata rata $46 \mathrm{~kg}$. dengan nilai minimum 41 $\mathrm{kg}$. dan nilai maximum60 kg.

Kenaikan berat badan selama kehamilan bervariasi untuk setiap wanita hamil. Total pertambahan berat badan selama hamil yang dianjurkan adalah dalam batas $10-12 \mathrm{~kg}$. Namun untuk ibu yang berat badannya kurang sebelum hamil harus kejar kekurangannya, jadi dianjurkan naik 12,5$18 \mathrm{~kg}$. Sementara ibu yang bobotnya agak berlebih, dianjurkan naik 7-11,5 $\mathrm{kg}$ saja selama kehamilan.

Hasil penelitian sesuai dengan penelitian Rahma (2016) Nurina Peningkatan status gizi ibu hamil wilayah operasional UPTD Puseksmas Pasirukem berdasarkan LILA ini terjadi dengan adanya kesadaran lebih baik terutama dalam konsumsi makanan utama dan PMT-P (susu dan biskuit MT-Bumil) selama masa kehamilan. Kesalahpahaman dalam konsumsi PMT-P sebagai makanan utama telah disampaikan oleh kader posyandu melalui kegiatan penyuluhan yang dilakukan pada saat pemantauan kader. Akan tetapi, kondisi penurunan BB dan tidak adanya peningkatan BB ibu hamil pun masih dapat ditemukan dalam 
pelaksanaanPMT-P ini. Kondisi ini dipengaruhi oleh faktor kurangnya konsumsi ibu hamil karena rasa bosan dengan makanan serta rasa mual.

Menurut asumsi peneliti dalam penelitian yang dilakukan di Wilayah Kerja Puskesmas Curug Kabupaten Tangerang Tahun 2018, kenaikan berat badan pada ibu hamil KEK sangat berpengaruh terhadap kenaikan LILA sehingga status gizi ibu hamil dapat meningkat, pemberain PMT pada ibu hamil KEK terutama pada trimester awal sangat penting dimana ibu dan janin sangat membutuhkan nilai gizi lebih untuk kesehatan ibu dan bayi, dimana pada trimester awal pola makan ibu sangat menurun diakrenakan mual muntah karena kehamilan

\section{Pengaruh Pemberian Makanan Tambahan dan Susu Terhadap Penabahan Berat Badan Pada Ibu Hamil KEK}

Hasil penelitian yang dilakukan tentang Pengaruh pemberian makanan tambahan dan susu ibu hamil terhadap kenaikan berat badan pada ibu hamil KEK di wilayah kerja Puskesmas Curug Kabupaten Tangerang dengan hasil rata rata berat badan sebelum di beri perlakuan $44 \mathrm{~kg}$ dengan standard deviasi 3,19 dan sesudah diberi perlakuan didapatkan hasil dengan rata rata $46 \mathrm{~kg}$ dengan standard deviasi 2,94. Terlihat juga peningkatan berat badan dengan rata rata 1,813 selain itu didapatkan nilai $\mathrm{P}=0,000<0,05$ maka didapatkan adanya pengaruh antara sebelum perlakuan dan setelah diberi perlakuan.

Kekurangan Energi Kronik (KEK) adalah salah satu keadaan malnutrisi. Dimana keadaan ibu menderita kekurangan makanan yang berlangsung menahun (kronik) yang mengakibatkan timbulnya gangguan kesehatan pada ibu secara relative atau absolut satu atau lebih zat gizi Keadaan KEK terjadi karena tubuh kekurangan satu atau beberapa jenis zat gizi yang dibutuhkan. Beberapa hal yang dapat menyebabkan tubuh kekurangan zat gizi antara lain jumlah zat gizi yang dikonsumsi kurang, mutunya rendah atau keduanya. Zat gizi yang dikonsumsi juga mungkin gagal untuk diserap dan digunakan untuk tubuh (Helena, 2013).

Hal ini sependapat dengan penelitian yang dilakukan oleh AASP. Chandradewi (2015) Hasil uji statistik pair $\mathrm{t}$ test, diperoleh nilai sig $0,000(\mathrm{p}<0.05)$, yang berarti bahwa pemberian makanan tambahan memberikan pengaruh yang signifikan terhadap kenaikan berat badan ibu hamil kurang energi kronis di Labuan Lombok Kabupaten Lombok Timur. Berdasarkan hasil penelitian dan urain teori di atas menurut analisis peneliti bahwa pemberian makanan tambahan dan susu ibu hamil sangat efektif meningkatkan berat badan ibu hamil dalam mengatasi KEK. karena terlihat dari hasil uji antara sebelum dan sesudah yang signifikan. Peran aktif pemerintah dalam penanganan ini sangatlah penting, dan untuk wilayah yang diteliti saat ini sudah dilakukan program pmt namun dalam pemantauan KEK belum maksimal. Sehingga dengan adanya penelitian ini menjadi sumber dan saran bagi instansi terkait dan tenaga kesehatan yang ada dilapangan.

\section{Kesimpulan}

Berdasarkan hasil penelitian pengaruh pemberian makanan tambahan dan susu ibu terhadap penambahan berat badan ibu hamil kek di wilayah kerja Puskesmas Curug Kabupaten Tangerang tahun 2018, dapat disimpulakan bahwa dari hasil penelitian didapatkan mean sebelum diberikan perlakuan 44 dan sesudah diberikaan perlakuan didapatkan hasil rata - rata $46 \mathrm{~kg}$ mean dari keduanya yaitu 1,813 dengan standar devisiasi 750 selain itu didapatkan juga nilai $\mathrm{P}=0,00<0,05$ maka didapatkan adanya pengaruh antara sebelum perlakuan dan setelah perlakuan.

Kepada Puskesmas Curug Kabupaten Tangerang untuk tetap melanjutkan program pemberian makanan tambahan pada ibu hamil, khususnya ibu hamil KEK dan juga melakukan pemantauan dan monitoring kepatuhan ibu hamil dalam 
melakukan pemeriksaan kehamilan. Selain itu hasil penelitian ini dapat menjadi sumber informasi dan menjadi referensi, sehingga dapat memberikan pengetahuan bagi mahasiswa khususnya pengetahuan mengenai manfaat pemberian makanan tambahan dan pendidikan kesehatan tentang gizi pada ibu hamil khususnya ibu hamil KEK. Adapun Hasil penelitian ini dapat dijadikan rujukan atau pembanding bagi penelitian selanjutnya, dan diharapkan

\section{Referensi}

Ai Yeyeh, R.2009. Asuhan Kebidanan I

(Kehamilan). Jakarta: Trans Info Media.

Alimul,Hidayat A.A., 2010. Metode Penelitian Kesehatan Paradigma Kuantitatif, Jakarta: Heath Books

Ana, Soumy.2010. Trimester Pertama Kehamilan Anda: Fase - Fase Paling Menebarkan. Yogyakarta: Buku Biru

Arisman. 2010. Gizi Dalam Daur Kehidupan. Jakarta:Penerbit Buku Kedokteran EGC

AASP.Chandradewi. 2015. Pengaruh Pemberian Makanan Tambahan Terhadap Peningkatan Berat Badan Ibu Hamil KEK (Kurang Energi Kronik) Di Wilayah Kerja Puskesmas Labuan - Lombok (1391 - 1420). Jurnal Kesehatan Prima Volume: 9, No.1, Februari 2015, Halaman: 1391-1402

Budiman. 2011. Penelitian Kesehatan Badung: Refika Aditama

Chandra, B. Metodologi Penelitian Kesehatan. Jakarta: EGC. 2013.

Depkes RI. 2008. Pedoman PWS (Pemantauan Wilayah Setempat) Gizi. Kementrian Kesehatan Jakarta

Dewi, dkk.2011. Asuhan Kehamilan untuk Kebidanan. Jakarta: Salemba Medika

Hani, Ummi, dkk.2011. Asuhan Kebidanan Pada Kehamilan Fisiologis. Jakarta: Salemba Medika

Helena, 2013. Gambaran Pengetahuan Gizi Ibu Hamil Trimester Pertama dan bagi peneliti selanjutnya dapat dilakukan penelitian dengan variabel lain yang lebih kompleks dan dengan metode lain. Bagi ibu hamil kek diharapkan kepada ibu hamil untuk memenuhi kebutuhan gizinya selama kehamilan dan teratur dalam melakukan pemeriksaan kehamilan. Sehingga dapat mencegah hal-hal yang tidak diinginkan dalam kehamilan dan persalinan, seperti kejadian anemia kehamilan atau bayi berat badan lahir rendah (BBLR).

Pola Makan dalam pemenuhan Gizi. www. repository.usu.ac.id. Diakses Tanggal 20 April 2015 Jam 15.00.wib

Hidayat, A. 2008. Ilmu Kesehatan Anak. Jakarta: Salemba Medika

Karyadi.2010. Panduan Lengkap Hamil Sehat. Yogyakarta:Diva Press

Kemenkes RI, 2018. Pedoman Penyelenggaraan Pemberian Makanan Tambahan pemulihan Bagi Ibu Hamil KEK dan balita Gizi Kurang. Kementrian Kesehatan Jakarta.

Kemenkes RI, 2017. Pedoman Penyelenggaraan Pemberian Makanan Tambahan pemulihan Bagi Ibu Hamil KEK dan balita Gizi Kurang. Kementrian Kesehatan Jakarta.

Kemenkes RI, 2012. Pedoman Penyelenggaraan Pemberian Makanan Tambahan pemulihan Bagi Ibu Hamil KEK dan balita Gizi Kurang. Kementrian Kesehatan Jakarta

Laila. S.A .2016. Fator - Faktor Yang Mempengaruhi Yang Berhubungan Kekurangan Energi Kronik (KEK) Pada Ibu Hamil Di Puskesmas Belimbing Padang 3546. Jurnal

KesehatanMedikaSaintika Volome 8 Nomor 1

Mandriwati,G.A. 2011. Asuhan Kebidanan Antenatal: Penuntun Belajar. Jakarta: EGC 
Mochtar. 2007. Sinopsis Obstetri. Jakarta: EGC

Notoatmodjo,S. 2012. Metodologi Penelitian Kesehatan. Jakarta: Rineka Cipta

Notoatmodjo,S. 2012. Metodologi Penelitian Kesehatan. Jakarta: Rineka Cipta

Nursalam. 2013. Metodologi Penelitian Ilmu Keperawatan: Pendekatan Praktis: Jakarta: SalembaMedika.

Nursalam. 2008. Konsep dan Penerapan Metodologi Penelitian Ilmu Keperawatan. Jakarta: Salemba Medika.

Pantiwati, dkk.2010. Asuhan Kebidanan 1. Jakarta: Nuha Medika

Prawirohardjo, Sarwono. 2010. Buku Acuan Nasional Pelayanan Kesehatan Maternal dan Neonatal. Jakarta: PT Bina Pustaka Sarwono Prawirohardjo.

Rahma Nurina .2016. Program Pemberian Makanan Tambahan untuk Peningkatan Status Gizi Ibu Hamil dan Balita di Kecamatan Cilamaya Kulon dan Cilamaya Wetan, Karawang. Jurnal CARE Jurnal Resolusi Konflik, CSR, dan Pemberdayaan Juni 2016, Vol. 1 (1): 44-49

Romauli, Suryat.2011. Buku Ajar Asuhan Kebidanan 1 Konsep Dasar Asuhan Kehamilan. Yogyakarta: Nuha Medika

Rukiyah, A.Y. dan Yulianti, I. Asuhan Kebidanan IV (Patologi Kebidanan). Jakarta:Trans Media.2010.

Sayogo. 2007. Gizi Pertumbuhan Remaja.Fakultas Kedokteran Fakultas Indonesia.Jakarta

Sofian.2011. Sinopsis Obstetri jilid 2.Jakarta : EGC

Sugiyono. 2012. Metode Penelitian Kuantitatif Kualitatif dan $R \& D$. Bandung: Alfabeta

Suryono, Khomsan A, Setiawan B, Martianto D, Sukandar D. 2007. Pengaruh pemberian susu terhadap indeks masa tubuh dan kepadatan tulang punggung remaja pria. Jurnal Gizi dan Pangan. 2(1): 1-7 Supariasa, dkk. 2012. "Penelitian status Gizi “. Jakarta:EGC.

Vivian. D.2011. Asuhan Kehamilan Untuk Kebidanan. Jakarta: Salemba Medika

WHO. 2015. Level and Trends in Child Mortality.http:www.who.int/maternal_chil d adolescent/document/level.trends_child_m ortality 